\title{
Assessment of the impact of risks of energy companies in a pandemic
}

\author{
Natalya Solopova ${ }^{1}$, Oleg Karpovich ${ }^{2}$, Anna Minnullina, ${ }^{3, *}$, and Ruslan Minnullin ${ }^{3}$ \\ ${ }^{1}$ Moscow State University of Civil Engineering (National Research University), Yaroslavskoye \\ Shosse, 26, Moscow, Russia \\ ${ }^{2}$ Diplomatic Academy of Ministry of Foreign Affairs of the Russian Federation, Ostozhenka str., \\ 53/2, Moscow, Russia \\ ${ }^{3}$ Industrial University of Tyumen, Volodarskogo str. 38, Tyumen, Russia
}

\begin{abstract}
The life-supporting role of the electric power industry during the spread of the coronavirus was especially pronounced. Electricity has become necessary for remote education of children, video calls, hospitals, etc. The main trends in electricity demand include changes in the ratio of electricity consumption in industry, transport and commercial sectors, as well as households due to the quarantine of some consumers. The paper identifies key risk-forming factors for the energy industry at the macro level and, based on an expert assessment, identifies the most probable and most powerful risks. By analogy with external risk-forming factors, the internal risk-forming factors of energy companies were analyzed, and their range of internal risks was determined.
\end{abstract}

\section{Introduction}

In 2020, the pandemic has had significant consequences for the development of most sectors of the economy of countries around the world. The life-supporting role of the electric power industry during the spread of the coronavirus was especially pronounced. Electricity has become essential for remote education of children, video calls, hospitals, and more. The main trends in the demand for electricity include:

- a decrease in electricity consumption in industry, transport and commercial sectors due to the quarantine of some consumers (closure of small and medium-sized businesses in the retail, service sector, decrease in the load of electric transport, partial restriction of the work of industry, etc.);

- a slight increase in electricity consumption in households and a change in the daily load schedule following the transition of people to a remote mode of work and study.

At the same time, indirect difficulties faced by almost all sectors of the economy also had an influence:

- restriction of work in quarantine zones;

- lack or absence of suppliers and contractors. This is especially important when it comes to large investment projects;

\footnotetext{
${ }^{*}$ Corresponding author: minnullinaay@yandex.ru
} 
- complexity of finding and attracting new personnel and improving the qualifications of existing employees;

- risk of diversification of suppliers if, for a known reason, they do not cope with the concluded contract or cannot fulfill it within the agreed time frame;

- errors in the calculation and construction of supply chains;

- occurrence of information leakage due to work on remote computers;

- a break or a complete stop of work on many investment projects;

- risk of entering into agreements with insolvent partners or with partners on the verge of bankruptcy;

- slowdown of staff work due to the transition of office workers to a remote format;

- and many others. [1-5]

These consequences inevitably affected the shortage of proceeds and working capital of almost all companies, which are so necessary in today's conditions in order to pay direct mandatory costs: salaries, rent, taxes, loans.

It should be noted that in the near future, the number of bankruptcies and non-payments will grow. The main thing in the current situation is to maintain financial independence and look for new opportunities and niches for the long-term development strategy of the company.

It is interesting that the transition of people to a remote mode of work, from houses and apartments, changed the daily schedule of electrical load. Its shape changes to typical for weekends - an additional daily peak appears, the load becomes more even throughout the day. And, more importantly, the requirements for the reliability of distribution networks are increasing, including in the suburbs.

The quarantine-related electricity demand pressure will last for several months. Longerterm trends of change will depend on the speed of economic recovery.

In Russia, according to SO UES JSC, the average decrease in electricity consumption was $6-7 \%$ during the first week of April, and during the second week - $3.2 \%$. The maximum reduction was achieved in the energy systems of the European part of Russia (Center IES, Volga IES, South IES) in the first days of April - up to 15-19\%, but by midApril it dropped to $3-7 \%$. IES of Siberia and the Far East showed no significant changes in electricity consumption by mid-May.

\section{Materials and methods}

To assess the composition and structure of risks of companies in the energy industry during a pandemic, it is necessary to identify risk-forming factors both at the macro and micro levels.

Studies have shown that in order to develop effective management decisions, the risk must be assessed by the following parameters: impact strength, probability of occurrence, and the possibility of a synergistic effect. In risk diagnostics, the most difficult task is the formalized description of uncertainty. Since most risks cannot be quantified, it is recommended to assess them using an expert survey.

Expert ranking of risks in the current practice is carried out using a table that simultaneously takes into account two parameters: the possible strength of the impact of risks and the likelihood of their occurrence. The data obtained in this way makes it possible to analyze the degree of concentration of risks, to highlight significant ones among them, and to determine the level of synergistic relationship between them. Although some scholars admit that risk ranking using this method may not be very accurate. The advantage of this approach is that it takes into account both the specific feature of the industry and the resistance of a particular company to the negative impacts of the external environment. In other words, the subjectivity of the expert assessment is compensated by the expert's 
competence in terms of understanding the functioning of the industry as a whole at the macro level, and by knowledge of the features of the economic and production functioning of a particular enterprise at the micro level.

From the total number of factors influencing risks described in the modern literature, their groups were identified that have the greatest impact on the activities of companies in the energy industry. Also, a number of factors caused by the state of the external environment and leading to the implementation of certain types of risks were classified in the analysis process as insignificant due to the low probability of implementation and the strength of the impact, and therefore were not included in the considered list of risks. [6.7]

The analyzed risk groups and the factors of their influence are presented in Table 1.

To obtain a complete picture of the risk spectrum of the industry, it is necessary, first of all, to study the risks that appear in the process of interaction between the enterprise and various subjects of the external economic environment. These include consumers of the company's products, suppliers, subcontractors, partners, creditors, banks, competing organizations, state and regional regulatory authorities, local government administrations, etc. Any relationship can become a risk-forming factor leading to the emergence of types of risks of different strength and synergy. The magnitude and likelihood of such risks, in turn, is largely determined by economic, political, demographic and other parameters of the industry dynamics. The nature of the current legislation, local customs, and the established practice of interaction of various subjects also have an impact.

Thus, the following macro-level risks are highlighted, which are caused by the nature of the interaction of energy companies with the economic and competitive environment: political, commercial, financial and innovation risks.

Political risks are one of the most dangerous risks, especially when companies carry out foreign economic activities, as they act as the main factors of uncertainty in the external economic environment. In general, political risks represent losses arising from the activities of the state. It is especially important to take into account this group of risks for enterprises operating in countries with a high level of political instability.

For the energy sector of Russia, political risks with a low degree of probability of realization take the following forms:

- introduction of economic sanctions limiting the volume of supplies and imports of high-tech energy technologies and equipment in both energy production and management, as well as investment activity of foreign counterparties;

- risks of strikes and suspension/termination of production due to the socio-political instability of the situation in the country.

Commercial risks are associated with losses arising in the process of carrying out the main activity of companies in the energy market. Besides, in a pandemic, the most probable risk factor is sharp fluctuations in demand for energy products. At the same time, demand changes its structure from production, industrial, and transport one to residential demand (households).

Most likely financial risks for the energy industry:

1. Risks of insolvency of counterparties and the share of debt receivables from companies. There is a sharp increase in the volume of net debt and a decrease in the overall level of profitability among the leading companies in the energy industry.

2. The probability of financial losses in the event of a change in the exchange rate. It is important to note that foreign exchange risk has a significant impact on the profitability of export-import operations carried out by enterprises.

3. Financial losses from investment activities. This group of risks is associated with the specifics of investing money in various assets. At the same time, the energy industry of Russia is characterized by such investment risks as: the volatility of the ruble exchange rate, the low rating of the current investment climate in Russia by the world's leading rating 
agencies, the massive withdrawal of foreign investments due to the destabilization of the political situation; informational risks associated with investing in projects in the absence of transparent, accurate and reliable information about the state of the market.

In a pandemic, it is also necessary to take into account the impact of innovation risks on companies in the energy industry, as there may be a slowdown in the introduction of advanced technologies and the commissioning of modern equipment. The cancellation and postponement of a large number of international conferences, exhibitions, fairs and other events promoting the exchange of experience and the growth of scientific and technological progress made their inevitable contribution to the slowdown in the development of the Russian energy sector.

For further study of the risk spectrum of the energy industry at the micro level, it is necessary to take into account the following features:

1. Any energy company is a large enterprise that carries political, strategic and social significance for a city or region, therefore it is important to take into account the cityforming factor when assessing risks at the micro level.

2. The state and efficiency of an individual company in the energy industry, due to the size of its financial and industrial capacities, have a significant impact on the industry as a whole at the regional level.

3. It is necessary to take into account the dependence of the activities of most energy companies on natural and climatic conditions, geographical location, conditions and opportunities to ensure effective logistics.

One of the most dangerous risks at the micro level in a pandemic are the risks directly related to management processes: lack of control over the effectiveness of the use of risk management tools; non-fulfillment of contracts; low information support within the company; lack of leadership competence in the current conditions; delay in making antirisk decisions.

Internal financial risks also have a significant impact on the activities of companies. Risk management aimed at countering intra-financial risks, as a rule, is focused on increasing companies' competitive advantages, increasing financial stability, etc. The absence of serious financial control, which should be provided by planning procedures and monitoring the implementation of decisions made, can lead to a significant increase in financial risk. This risk is usually associated with excessive use of borrowed capital and, as a result, loss of liquidity, increased transaction costs, cash shortages, etc. Also, the companies in the energy industry are prone to the risk of delays in wage payments, which may result in strikes and the suspension or complete cessation of production activities, resulting in disruption of supplies, a decrease in the level or loss of business reputation.

Environmental problems are becoming increasingly important for various types of companies. In this regard, it is also important to take them into account for the competent management of environmental risks: the development and implementation of environmentally friendly and resource-saving technologies, minimization of negative consequences, economic incentives for economic entities that respect the environment.

With regard to the energy industry, the following technical and production risks of companies were identified:

- a high degree of wear and tear of production assets, which increases the likelihood of equipment failure;

- equipment downtime under quarantine conditions;

-termination of the modernization of production dependent on imported equipment/software in the context of a reduction in export-import relations. 
Table 1. Main groups of risks and factors of their influence on companies in the energy industry, taking into account the pandemic.

\begin{tabular}{|c|c|c|}
\hline Risk level & Risk group & Risk influencing factors \\
\hline \multirow{4}{*}{ Macro level } & Political risks & $\begin{array}{l}\text { - political instability in the country } \\
\text { - imposition of sanctions } \\
\text { - restrictions on crossing external and internal borders } \\
\text { - tightening of protectionist policies } \\
\text { - tightening of barriers to market entry } \\
\text { - restrictions on currency conversion } \\
\text { - changes in legislation } \\
\text { - possibility of military conflicts }\end{array}$ \\
\hline & $\begin{array}{l}\text { Commercial } \\
\text { risks }\end{array}$ & $\begin{array}{l}\text { - sharp fluctuations in demand for energy products } \\
\text { - increased competition } \\
\text { - negative price dynamics } \\
\text { - reduction in demand due to quarantine and closure of production } \\
\text { - an increase in energy prices } \\
\text { - an increase in prices for raw materials and supplies }\end{array}$ \\
\hline & Financial risks & $\begin{array}{l}\text { - currency fluctuations } \\
\text { - inflation } \\
\text { - change in the refinancing rate } \\
\text { - tightening of the tax system } \\
\text { - insolvency of counterparties } \\
\text { - portfolio risk } \\
\text { - financial losses from investment activities } \\
\text { - growth of accounts receivable }\end{array}$ \\
\hline & $\begin{array}{c}\text { Innovative } \\
\text { risks }\end{array}$ & $\begin{array}{l}\text { - abrupt increase in scientific and technical progress } \\
\text { - development and implementation of advanced technologies by } \\
\text { competitors } \\
\text { - industrial espionage } \\
\text { - emergence of new types of energy products }\end{array}$ \\
\hline \multirow{6}{*}{ Micro level } & $\begin{array}{l}\text { Production } \\
\text { risks }\end{array}$ & $\begin{array}{l}\text { - incidental costs } \\
\text { - equipment downtime } \\
\text { - reduction of the planned volumes of production and sales of energy } \\
\text { products } \\
\text { - growth of the wage fund } \\
\text { - dependence on imported equipment and software } \\
\text { - technical complexity of the reorientation of production activities }\end{array}$ \\
\hline & $\begin{array}{l}\text { Internal } \\
\text { financial risks }\end{array}$ & $\begin{array}{l}\text { - ineffective distribution of financial flows within the corporate structure } \\
\text { - loss of liquidity } \\
\text { - an increase in the volume of net debt } \\
\text { - transactional risk } \\
\text { - wrong choice of object for investment } \\
\text { - risks of delays in salary payments }\end{array}$ \\
\hline & $\begin{array}{l}\text { Internal } \\
\text { commercial } \\
\text { risks }\end{array}$ & $\begin{array}{l}\text { - incorrect price positioning } \\
\text { - insufficient segmentation of sales markets } \\
\text { - dependence on market tariffs } \\
\text { - violation of optimized supply volumes } \\
\text { - lack of a quality management system } \\
\text { - non-fulfillment of contracts for the release of products } \\
\text { - violation of the document flow process } \\
\text { - low information support within the company }\end{array}$ \\
\hline & $\begin{array}{l}\text { Environmental } \\
\text { risks }\end{array}$ & $\begin{array}{l}\text { - depletion of non-renewable resources } \\
\text { - falling under fines and restrictions caused by violation of environmental } \\
\text { standards } \\
\text { - an increase in the level of environmental pollution }\end{array}$ \\
\hline & Labor risks & $\begin{array}{l}\text { - mistakes of management personnel } \\
\text { - lack of qualified personnel } \\
\text { - weakening of production discipline } \\
\text { - low corporate culture } \\
\text { - decrease in labor productivity }\end{array}$ \\
\hline & $\begin{array}{l}\text { Technical } \\
\text { risks }\end{array}$ & $\begin{array}{l}\text { - risk of equipment downtime } \\
\text { - moral and physical wear and tear of fixed assets }\end{array}$ \\
\hline
\end{tabular}


For an expert assessment of the most significant risks in a pandemic, a number of surveys were conducted among analysts, engineers, and top managers of energy service companies.

The expert assessment assumed the determination of two main parameters characterizing the risks on the basis of the proposed empirical scales: [7]

1) strength of the negative impact of risk (range of the empirical scale is from 0 to 10);

2) likelihood of risk occurrence in the company (range of the empirical scale is from 0 to 1)

The results of assessing the influence of the factor and the likelihood of risk realization are ranked and presented in Table 2.

Table 2. Expert characteristics of the given parameters of risk assessment.

\begin{tabular}{|c|c|c|}
\hline $\begin{array}{l}\text { Risk assessment } \\
\text { parameters }\end{array}$ & Accepted scale & Scale value characteristic \\
\hline \multirow{5}{*}{$\begin{array}{l}\text { 1. Strength of the } \\
\text { negative impact of risk }\end{array}$} & from 0 to 2.0 & Insignificant \\
\hline & from 2.1 to 4.0 & Low \\
\hline & from 4.1 to 6.0 & Huge \\
\hline & from 6.1 to 8.0 & Significant \\
\hline & from 8.1 to 10.0 & Critical \\
\hline \multirow{5}{*}{$\begin{array}{l}\text { 2. Likelihood of risk } \\
\text { occurrence in the } \\
\text { company }\end{array}$} & from 0 to 0.20 & Insignificant \\
\hline & from 0.21 to 0.40 & Substantial \\
\hline & from 0.41 to 0.60 & High \\
\hline & from 0.61 to 0.80 & Maximum \\
\hline & from 0.81 to 1.0 & Critical \\
\hline
\end{tabular}

In the course of the study, experts made an assessment according to the two abovementioned main parameters, and the results of the study were recorded in a questionnaire, according to which a macro and micro-level risk profile was subsequently built. The choice of experts included in the final table of the risk profile was carried out on the basis of the ranking method using the Spearman's rank correlation coefficient calculated by the formula:

$$
P_{x y}=1-\frac{6 \sum d_{i}^{2}}{n\left(n^{2}-1\right)}
$$

$d_{i}^{2}$ - rank difference squared; $\mathrm{n}$ - number of observations (number of pairs of ranks).

According to this method, all experts whose level of the value of the correlation coefficient of ranks in terms of strength and probability of risk realization exceeded $50 \%$ were considered statistically significant, and the rest were excluded from the sample.

As a result of taking into account the proposed two parameters analyzed, a quantitative assessment of macro and micro-level risks is carried out by calculating the degree of risk. In general terms, the degree of risk is the probability of a loss event occurring, as well as the amount of possible damage from it.

To determine the degree of risk, it must be calculated using the formula (2):

$$
R_{j}=W_{j} C_{j}
$$

$R_{j}$ - degree of j-th risk; $W_{j}$ - probability of occurrence of the j-th risk; $C_{j}$ - strength of the negative impact of the $\mathrm{j}$-th risk. 


\section{Results}

In order to understand in more detail which factors influencing risks have the greatest destabilizing effect on the activities of companies in the energy industry, a matrix was formed on the basis of the strength of their impact and the likelihood of implementation (Table 3). It should be noted that this table included all risks with an average or higher probability of an undesirable outcome. Also, risks with a low probability of realization, but with a high level of negative impact on the results of activities of economic entities were included [8-11].

Table 3. Expert ranking of the main risks of the energy industry at the macro level.

\begin{tabular}{|c|c|c|c|c|c|c|c|c|c|c|c|c|c|}
\hline \multirow{2}{*}{ Risks } & \multicolumn{10}{|c|}{ Expert risk assessment } & \multirow{2}{*}{ 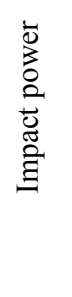 } & \multirow{2}{*}{ 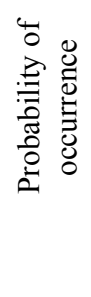 } & \multirow{2}{*}{ 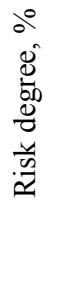 } \\
\hline & 1 & 2 & 3 & 4 & 5 & 6 & 7 & 8 & 9 & 10 & & & \\
\hline Inflation & 8 & 7 & 7 & 9 & 8 & 6 & 8 & 9 & 7 & 8 & 7.70 & 0.79 & 6.10 \\
\hline Currency rate fluctuations & 8 & 7 & 8 & 8 & 7 & 8 & 7 & 9 & 8 & 7 & 7.70 & 0.83 & 6.37 \\
\hline Imposition of sanctions & 5 & 6 & 5 & 6 & 6 & 5 & 5 & 6 & 5 & 5 & 5.40 & 0.62 & 3.36 \\
\hline $\begin{array}{l}\text { Insolvency of } \\
\text { counterparties }\end{array}$ & 7 & 6 & 8 & 7 & 8 & 6 & 8 & 6 & 7 & 8 & 7.10 & 0.58 & 4.09 \\
\hline $\begin{array}{l}\text { Financial losses from } \\
\text { investment detail }\end{array}$ & 9 & 8 & 9 & 9 & 8 & 9 & 8 & 8 & 8 & 9 & 8.50 & 0.51 & 4.30 \\
\hline $\begin{array}{l}\text { Growth of accounts } \\
\text { receivable }\end{array}$ & 5 & 6 & 5 & 4 & 5 & 4 & 5 & 4 & 5 & 6 & 4.90 & 0.71 & 3.46 \\
\hline Increased competition & 7 & 8 & 7 & 8 & 7 & 7 & 6 & 7 & 8 & 7 & 7.20 & 0.70 & 5.06 \\
\hline Negative price dynamics & 9 & 8 & 9 & 8 & 9 & 8 & 9 & 8 & 8 & 8 & 8.40 & 0.83 & 7.01 \\
\hline $\begin{array}{l}\text { Reducing demand for } \\
\text { main types of products }\end{array}$ & 8 & 9 & 8 & 8 & 9 & 7 & 8 & 9 & 9 & 7 & 8.20 & 0.76 & 6.22 \\
\hline $\begin{array}{l}\text { Excess supply of goods on } \\
\text { the market }\end{array}$ & 9 & 8 & 9 & 9 & 8 & 8 & 9 & 8 & 8 & 9 & 8.50 & 0.84 & 7.17 \\
\hline $\begin{array}{l}\text { Expansion to the market } \\
\text { by exporters }\end{array}$ & 5 & 5 & 6 & 5 & 6 & 5 & 5 & 6 & 5 & 6 & 5.40 & 0.58 & 3.14 \\
\hline Growth in transport costs & 5 & 4 & 3 & 6 & 4 & 5 & 4 & 5 & 6 & 5 & 4.70 & 0.73 & 3.41 \\
\hline $\begin{array}{l}\text { Expansion to the market } \\
\text { by exporters }\end{array}$ & 5 & 5 & 6 & 5 & 6 & 5 & 5 & 6 & 5 & 6 & 5.40 & 0.58 & 3.14 \\
\hline Increase in energy prices & 4 & 5 & 6 & 5 & 6 & 5 & 6 & 5 & 6 & 4 & 5.20 & 0.51 & 2.66 \\
\hline $\begin{array}{l}\text { Increase in the price of } \\
\text { raw materials and supplies }\end{array}$ & 5 & 6 & 5 & 7 & 5 & 7 & 5 & 6 & 7 & 5 & 5.80 & 0.61 & 3.54 \\
\hline
\end{tabular}

Also, for a more detailed analysis of risk-forming factors, based on the strength of their impact and the likelihood of implementation, a matrix was formed (Table 4), which 
includes the ten most significant risk-forming factors affecting companies in the energy industry at the micro level $[10,11]$.

Table 4. Expert ranking of the main microeconomic risks of the energy industry.

\begin{tabular}{|c|c|c|c|c|c|c|c|c|c|c|c|c|c|}
\hline \multirow[b]{2}{*}{ Risks } & \multicolumn{10}{|c|}{ Expert risk assessment } & \multirow[b]{2}{*}{ 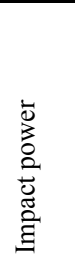 } & \multirow[b]{2}{*}{ 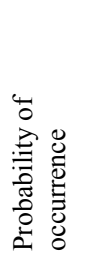 } & \multirow[b]{2}{*}{ 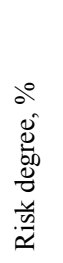 } \\
\hline & 1 & 2 & 3 & 4 & 5 & 6 & 7 & 8 & 9 & 10 & & & \\
\hline Lack of qualified personnel & 6 & 4 & 5 & 5 & 6 & 8 & 6 & 5 & 6 & 7 & 5.80 & 0.69 & 3.99 \\
\hline Increase in net debt & 8 & 7 & 8 & 8 & 9 & 7 & 9 & 8 & 7 & 8 & 7.90 & 0.74 & 5.82 \\
\hline Management errors & 9 & 8 & 9 & 9 & 8 & 8 & 8 & 9 & 9 & 8 & 8.50 & 0.68 & 5.75 \\
\hline $\begin{array}{l}\text { Decrease in the planned } \\
\text { volumes of production and } \\
\text { sales of energy products }\end{array}$ & 7 & 5 & 5 & 7 & 5 & 6 & 5 & 6 & 5 & 6 & 5.70 & 0.64 & 3.65 \\
\hline Loss of liquidity & 8 & 8 & 6 & 9 & 8 & 9 & 8 & 9 & 8 & 9 & 8.20 & 0.53 & 4.33 \\
\hline $\begin{array}{l}\text { Wrong choice of object for } \\
\text { investment }\end{array}$ & 7 & 6 & 7 & 7 & 6 & 6 & 8 & 6 & 7 & 6 & 6.60 & 0.39 & 2.60 \\
\hline $\begin{array}{l}\text { Falling under fines and } \\
\text { restrictions caused by } \\
\text { violation of environmental } \\
\text { regulations }\end{array}$ & 6 & 6 & 7 & 7 & 6 & 7 & 8 & 7 & 7 & 6 & 6.70 & 0.65 & 4.35 \\
\hline $\begin{array}{l}\text { Moral and physical wear } \\
\text { and tear of fixed assets }\end{array}$ & 7 & 6 & 7 & 8 & 6 & 8 & 7 & 8 & 7 & 8 & 7.20 & 0.83 & 5.97 \\
\hline Violation of delivery times & 5 & 4 & 3 & 5 & 3 & 4 & 3 & 4 & 5 & 3 & 3.90 & 0.64 & 2.51 \\
\hline
\end{tabular}

\section{Discussions}

Thus, on the basis of expert ranking, one of the most dangerous risk-forming factors for companies in the energy industry at the micro level are labor risks caused by mistakes of management personnel and a shortage of qualified personnel, risks associated with an increase in debt obligations and a decrease in liquidity, as well as the risk of a reduction in planned production volumes and the sale of energy products. The negative dynamics associated with a decrease in the planned volumes of production and sales of products clearly correlates with the general market recessive state of the industry.

Financial and political risks also significantly increase the negative dynamics of the market. In view of the emerging global financial crisis, there is a negative dynamics of fluctuations in world currencies, interest rates on loans are growing, many infrastructure projects are frozen, which, in turn, significantly slows down the processes of investment in the production of high-tech types of energy products.

\section{References}

1. V.V. Kondratiev, Organization of energy conservation (energy management) 108 (2010)

2. M. Didushkova, M. Votapek, Portal-energo, http://portal-energo.ru/files/articles/portalenergo_ru_chehiya.docx 
3. T.L. Barton, Making Enterprise Risk Management Pay Off: How Leading Companies Implement Risk Management (Moscow: Williams, 2008)

4. P.G. Grobovoy, Risks in modern business (Moscow: Infra-M, 2012)

5. A.B. Chapaev, Yu.G. Bozieva, The online journal Science of Science 5(30), 1-9 (2015)

6. E.A. Yayli, What we want to define, assess, and what we want to manage, Methodological aspects of the problem of risk, Risk management (Moscow: Ankil LLC, 2006)

7. N.I. Leiman, Education Advisor 1, 52-56 (2011)

8. A. Minnullina, Advances in Intelligent Systems and Computing 692, 1224-1233 (2018) doi: 10.1007/978-3-319-70987-1_131

9. A. Minnullina, E3S Web of Conferences 33, 03060 (2018) doi:10.1051/e3sconf/20183303060

10. N. Zotkina, Advances in Intelligent Systems and Computing, 692, 1204-1213 (2018) doi: 10.1007/978-3-319-70987-1_129

11. Tanic, M., Stankovic, D., Nikolic, V., Nikolic, M., Kostic, D., Milojkovic, A., Spasic, S., Vatin, N. Procedia Engineering. 2015. 117(1). Pp. 919-932. DOI:10.1016/j.proeng.2015.08.179.

12. N. Khamrakulova, O. Dzyubinsky, T.M. Tsybzhitova, UNECE on Energy 104 (2013)

13. N. Martynov, et al. Journal of Physics: Conference Series 1614, 012060 (2020) doi:10.1088/1742-6596/1614/1/012060 